Сергій Горбачевський, кандидат технічних наук, старший науковий співробітник Національний університет оборони України імені Івана Черняховського, м. Київ

ORCID ID 0000-0002-4946-1604

Михайло Орда, кандидат технічних наук, старший науковий співробітник Національний університет оборони України імені Івана Черняховського, м. Київ

ORCID ID 0000-0003-0374-3881

Ігор Плохута,

Національний університет оборони України імені Івана Черняховського, м. Київ

ORCID ID 0000-0002-6556-294X

Михайло Черненок, Національний університет оборони України імені Івана Черняховського, м. Київ

ORCID ID 0000-0001-5376-6606

DOI: $10.33099 / 2617-1775 / 2019-02 / 46-51$

\title{
ДЕЯКІ ОСОБЛИВОСТІ ПРОВЕДЕННЯ АТЕСТАЦІЇ ВВНЗ У ЧАСТИНІ ПРОВАДЖЕННЯ НАУКОВОЇ І НАУКОВО-ТЕХНІЧНОЇ ДІЯЛЬНОСТІ
}

У статті визначені особливості проведення атестації ВВНЗ у частині провадження ними наукової $i$ науково-технічної діяльності та розроблені пропозиції до відповідної методики очінювання.

Ключові слова: вищі військові навчальні заклади; атестачія; науковий напрям; науково-технічна діяльність; методика; система показників.

Постановка проблеми. Державна атестація закладів вищої освіти здійснюється відповідно до Закону України "Про наукову i науково-технічну діяльність" [1] і включає комплекс заходів щодо оцінювання ефективності діяльності закладів вищої освіти за науковими напрямами. В той же час атестація військових вищих навчальних закладів (далі ВВНЗ) має деякі особливості, які обумовлені специфікою військової науки і вони мають найти своє відображення у методиці оцінювання ВВНЗ у частині провадження ними наукової і науково-технічної діяльності (ННТД).

Аналіз останніх досліджень. Оцінка ефективності науково-технічної діяльності вивчалась багатьма вітчизняними та зарубіжними вченими [4-6], але до закінченої методики оцінювання закладу вищої освіти (далі 3ВО) справа не доходила. Перша методика (далі Методика) державної атестації ЗВО з’явилась в 2019 році та була введена в дію наказом Міністерства освіти і науки (MOH) України 12.03.2019 №338 [2,3] 
Метою статті є визначення особливостей проведення атестації ВВНЗ у частині провадження ними наукової і науково-технічної діяльності та розробка пропозицій до відповідної методики оцінювання МОН.

Виклад основного матеріалу дослідження. Результати державної атестації ВВНЗ використовуються Міністерством оборони України та Генеральним штабом Збройних Сил України під час:

планування обсягу видатків державного бюджету для забезпечення діяльності ВВНЗ;

формування тематики наукових досліджень та науково-технічних розробок ВВН3;

розгляду питання щодо реорганізації та ліквідації ВВНЗ.

Військова наука має три дуже суттєвих відмінності від цивільної науки взагалі и наукової діяльності, яка проваджується у цивільних закладах вищої освіти.

По-перше, військова наука має директивний спосіб управління. Більшість НДР у ВВНЗ виконуються на замовлення керівників структурних підрозділів МО України та ЗС України. Тому наукові-дослідні роботи виконуються за рахунок утримання і такі наукометрічні показники, як гранти, залучені на дослідження кошти та інші не можуть використовуватися в якості показників наукової та науково-технічної діяльності ВВНЗ. По-друге, результаті наукової діяльності ВВНЗ зазвичай мають закритий характер і тому застосування традиційних показників публікацій у Scopus та Web of Science не $\epsilon$ показовим. И третє - тільки військові ВНЗ проводять наукову та науковотехнічну діяльність за науковим напрямом "Воєнні науки та національна безпека ". За іншими науковими напрямами атестація здійснюється за наказом МОН України №338. Для урахування цих особливостей пропонується:

1. Доповнити систему показників, за якими оцінюсться ВВНЗ, показниками $\boldsymbol{P}_{14}-\boldsymbol{P}_{17}$, де

$\boldsymbol{P}_{14}$ - кількість працівників ВВНЗ (за основним місцем роботи), які залучались до розробки та/або експертизи загальнодержавних нормативних та керівних документів з питань реалізації воєнної політики України та розвитку сил оборони ;

$\boldsymbol{P}_{15}$ - кількість працівників ВВНЗ (за основним місцем роботи), які залучались до розробки або модернізації (наукового супроводження розробки або модернізації) зразків ОВТ, спец обладнання та іншого в інтересах МО України;

$\boldsymbol{P}_{16}$ - кількість працівників ВВНЗ (за основним місцем роботи), які залучались до проведення досліджень на заходах оперативної, бойової або мобілізаційної підготовки, що проводились відповідно до планів ГШ ЗС України та МО України;

$\boldsymbol{P}_{17}$ - обсяг заходів, що було виконано згідно річних звітів з ННТД;

2. доповнити систему питомих показників (індикаторів) індикаторами $\boldsymbol{k}_{12}-\boldsymbol{k}_{16}$, де 
$\boldsymbol{k}_{12}$ - питомий показник кількості працівників ВВНЗ (за основним місцем роботи), які залучались до розробки та/або експертизи загальнодержавних нормативних та керівних документів 3 питань реалізації воєнної політики України та розвитку сил оборони

$$
k_{12}=\frac{P_{14}}{\Pi_{1}+\Pi_{4}+\Pi_{5}+\Pi_{6}}
$$

$\boldsymbol{k}_{13}$ - питомий показник кількості працівників ВВНЗ (за основним місцем роботи), які залучались до розробки або модернізації (наукового супроводження розробки або модернізації) зразків ОВТ, спец обладнання та іншого в інтересах МО України

$$
k_{13}=\frac{P_{15}}{\Pi_{1}+\Pi_{4}+\Pi_{5}+\Pi_{6}}
$$

$\boldsymbol{k}_{14}$ - питомий показник кількості працівників ВВНЗ (за основним місцем роботи), які залучались до проведення досліджень на заходах оперативної, бойової або мобілізаційної підготовки, що проводились відповідно до планів ГШ ЗС України та МО України

$$
k_{14}=\frac{P_{16}}{\Pi_{1}+\Pi_{4}+\Pi_{5}+\Pi_{6}}
$$

$\boldsymbol{k}_{15}$ - питомий показник обсягу годин, що виконується за науковим напрямом працівником ВВНЗ (за основним місцем роботи)

$$
k_{14}=\frac{P_{17}}{\Pi_{1}+\Pi_{4}+\Pi_{5}+\Pi_{6}}
$$

$\boldsymbol{k}_{16}$ - показник обсягу робіт, що здійснюються ВВНЗ за науковим напрямом

$$
k_{16}=P_{17} \text {, де }
$$

$\boldsymbol{\Pi}$ - показники оцінки наукового потенціалу ВВНЗ, а саме

$\boldsymbol{\Pi}_{1}$ - чисельність штатних науково-педагогічних працівників

$\boldsymbol{\Pi}_{4}$ - чисельність штатних наукових працівників науково-дослідних підрозділів

$\boldsymbol{\Pi}_{5}$ - чисельність ад'юнктів

$\boldsymbol{\Pi}_{6}$ - чисельність докторантів

\section{3. запропонувати наступні значення вагових коефіціснтів}

(коефіцієнтів пріоритетності) для наукового напряму "Воєнні науки та національна безпека"

\begin{tabular}{|c|c|c|c|c|c|c|c|c|c|c|c|c|c|c|c|c|c|}
\hline $\begin{array}{c}\text { № } \\
3 / \Pi\end{array}$ & $\begin{array}{c}\text { Науковий } \\
\text { напрям }\end{array}$ & $a_{1}$ & $a_{2}$ & $a_{3}$ & $a_{4}$ & $a_{5}$ & $a_{6}$ & $a_{7}$ & $a_{8}$ & $a_{9}$ & $a_{10}$ & $a_{11}$ & $a_{12}$ & $a_{13}$ & $a_{14}$ & $a_{15}$ & $a_{16}$ \\
\hline 1 & $\begin{array}{l}\text { Воєнні } \\
\text { науки та } \\
\text { національна } \\
\text { безпека }\end{array}$ & 0,06 & 0,06 & 0,05 & 0,05 & 0,06 & 0,07 & 0,06 & 0,05 & 0,05 & 0,05 & 0,08 & 0,08 & 0,08 & 0,08 & 0,05 & 0,07 \\
\hline
\end{tabular}

Сума значень вагових коефіцієнтів для наукового напряму дорівнює 1.

Розраховані індикатори $k_{i}$ нормуються за такою формулою: 


$$
k_{i}^{\prime}=\frac{k_{i}-k_{i \min }}{k_{i} \max -k_{i \min }}
$$

де $k_{i}^{\prime}$ - нормований питомий показник результативності (нормований індикатор) конкретного ВВНЗ за науковим напрямом;

$k_{i \min }$ та $k_{i \max }-$ мінімальне та максимальне значення питомих показників результативності (індикаторів) за науковим напрямом серед усіх ВВН3, що беруть участь у державній атестації.

Загальна інтегральна оцінка наукового напряму ВВНЗ $\left(K_{j}\right)$ розраховується як адитивна нелінійна згортка $k_{i}^{\prime}$ за такою формулою:

$$
K=\sqrt{\sum_{i=1}^{n}\left(a_{i} \cdot k_{i}^{\prime}\right)^{2}},
$$

де:

$a_{i}$ - ваговий коефіцієнт (коефіцієнт пріоритетності), $n=16$.

Отримані значення $K$ нормуються та переводяться у 100-бальну шкалу за такою формулою:

$$
K^{100}=\frac{K-K_{\min }}{K_{\max }-K_{\min }} \cdot 100,
$$

де $K_{\min }$ та $K_{\max }$ - мінімальне та максимальне значення загальної інтегральної оцінки наукового напряму ВВНЗ серед усіх ВВНЗ, що беруть участь у державній атестації за науковим напрямом;

$K^{100}$ - атестаційна оцінка - індивідуальна характеристика досягнень ВВНЗ за науковим напрямом, відповідно до якої ВВНЗ належить до однієї 3 кваліфікаційних груп, для якої $K^{100}$ знаходиться в межах:

до групи А - від 87,5 до 100 балів;

до групи Б - від 52,5 до 87,5 бала (включно);

до групи В - від 20 до 52,5 бала;

до не атестованих - нижче ніж 20 балів.

Висновки. Запропоновані зміни до методики державної атестації дозволяють врахувати особливості впровадження ННТД за науковим напрямом "Воєнні науки та національна безпека"

\section{ЛІТЕРАТУРА}

1. Закон України "Про наукову і науково-технічну діяльність"

2. Постанова Кабінету Міністрів України від 22.08.2018 № 652 "Деякі питання проведення державної атестації закладів вищої освіти в частині провадження ними наукової (науково-технічної) діяльності ” 
3. Наказ Міністерства освіти і науки України від 12.03.2019 № 338 "Про державну атестацію закладів вищої освіти в частині провадження ними наукової (науково-технічної) діяльності"

4. Куркова О. П. Организация и планирование научно-технических исследований и разработок : монография. СПб. : Наукоемкие технологии, 2018. - 245 с.

5. Кислий В.М. Організація наукових досліджень: навчальний посібник Суми: Університетська книга. 2016. - 224 с.

6. Стеченко Д.М., Чмир О.С. Методологія наукових досліджень: підручник. - К.: Знання, 2005. 309 с.

\section{REFERENCES}

1. Zakon Ukrainy "Pro naukovu i naukovo-tekhnichnu diialnist"

2. Postanova Kabinetu Ministriv Ukrainy vid 22.08.2018 № 652 “Deiaki pytannia provedennia derzhavnoi atestatsii zakladiv vyshchoi osvity $\mathrm{v}$ chastyni provadzhennia nymy naukovoi (naukovo-tekhnichnoi) diialnosti "

3. Nakaz Ministerstva osvity i nauky Ukrainy vid 12.03.2019 № 338 “Pro derzhavnu atestatsiiu zakladiv vyshchoi osvity v chastyni provadzhennia nymy naukovoi (naukovotekhnichnoi) diialnosti "

4. Kurkova O. P. Orhanyzatsyia y planyrovanye nauchno-tekhnycheskykh yssledovanyi y razrabotok : monohrafyia. SPb. : Naukoemkye tekhnolohyy, 2018. - 245 s.

5. Kyslyi V.M. Orhanizatsiia naukovykh doslidzhen: navchalnyi posibnyk Sumy: Universytetska knyha. 2016. - 224 s.

6. Stechenko D.M., Chmyr O.S. Metodolohiia naukovykh doslidzhen: pidruchnyk. - K.: Znannia, 2005. $309 \mathrm{~s}$.

\section{PЕЗЮМЕ}

Сергей Горбачевский, кандидат технических наук, старший научный сотрудник

Национальный університет обороны Украины имени Ивана Черняховского, г. Киев

Михаил Орда,

кандидат технических наук, старший научный сотрудник

Национальный університет обороны Украины имени Ивана Черняховского, г. Киев

Игорь Плохута,

Национальный університет обороны Украины имени Ивана Черняховского, г. Киев

Михаил Черненок,

Национальный університет обороны Украины имени Ивана Черняховского, г. Киев

\section{Некоторые особенности проведения аттестации ВВУЗов в части научно-технической деятельности}

В статье определены особенности проведения аттестации ВВУЗов в части проведения ними научной и научно-технической деятельности и выработаны предложения $в$ соответствуюшую методику оценивания.

Ключевые слова: высшие военные учебные заведения; аттестация; научное направление; научно-техническая деятельность; методика; система показателей.

\section{SUMMARY}


Serhii Horbachevsky,

PhD (technical sciences), Senior Researcher

National University of Defence of Ukraine

Named after Ivan Chernyakhovskyi, c. Kyiv

Mikhailo Orda,

$\mathrm{PhD}$ (technical sciences), Senior Researcher

National University of Defence of Ukraine

Named after Ivan Chernyakhovskyi, c. Kyiv

Igor Plohuta,

National University of Defence of Ukraine Named after Ivan Chernyakhovskyi, c. Kyiv

Mikhailo Chernenok,

National University of Defence of Ukraine

Named after Ivan Chernyakhovskyi, c. Kyiv

\section{Attestation of science and technical activities in High Military Education Institutions: same aspects}

Introduction results of state attestation higher military educational establishment to be victorious by the Ministry of Defense of Ukraine and the General Staff of the Ukrainian Defense Forces hourly plan oaths of views of the sovereign budget for securing the duty higher military educational establishment.

Purpose the purpose of the article is to determine the features of performance appraisal higher military educational establishment in the part of carrying and scientific-technical activities and development of proposals to the appropriate evaluation method the Ministry of Education and Science of Ukraine from.

Methods the system of general scientific and special methods of theoretical and empirical research, namely theoretical and methodological analysis of the problem, analysis of scientific literature on the problem of research, systematization and generalization of scientific information concerning the nature and content of certain tasks, monitoring of existing systems were used to solve the set research problems. training of military specialists in the Russian Armed Forces, scientific generalization, general scientific methods of logical and comparative analysis, systematic approach, expert zinc, analysis and interpretation of theoretical and empirical data.

Results the result of the article is a set of indicators of scientific activity of military universities and their procedure their convolution into an integral estimate.

Originality the article first elaborates the method of attestation of military universities in the scientific direction "Military Sciences and National Security".

Conclusion The proposed changes to the methodology of state attestation allow to take into account the peculiarities of the implementation of NSTD in the scientific area "Military Sciences and National Security"

Key words: military education system; attestation; scientific direction; scientific and technical activity; methodology; system of indicators. 